\title{
ŪMI MEZENTERINIŲ ARTERIJŲ OKLIUZIJA. ETIOLOGIJA, DIAGNOSTIKA, GYDYMAS
}

\author{
Juozas Rimkus \\ Vilniaus universiteto Medicinos fakultetas
}

\begin{abstract}
Raktažodžiai: ūmi mezenterinè išemija, viršutinès mezenterinès arterijos okliuzija, ūmios mezenterinès išemijos diagnostika.
\end{abstract}

\section{Santrauka \\ Ūmi mezenterinè išemija (ŪMI) - tai staigiai sumažè- jusi ar visiškai nutrūkusi kraujo tėkmè ị plonąą žarną ar jos segmentą. Nepaisant tobulëjančios diagnostikos ir gydymo, mirštamumas nuo šios ligos yra labai aukštas. Tyrimo tikslas - aptarti ūmios mezenterinès išemijos etiologiją, diagnostiką ir gydymą. \\ Literatūros paieška atlikta PubMed, ScienceDirect, Up- ToDate duomenų bazèse. Iš viso atrinkta ir išanalizuota 10 publikacijų, paskelbtų 2013-2020 metų laikotarpiu. Rezultatai. Ūmi viršutinès mezenterinès arterijos okliu- zija gali atsirasti dèl dviejų priežasčių: embolija arba trombozè. Itariant ŪMI, svarbu išsiaiškinti embolijos ir trombozès riziką didinančius paciento rizikos veiks- nius. Pradiniai ŪMI požymiai ir laboratoriniai tyrimai nespecifiški, todèl ligą diagnozuoti sudètinga. Diagno- zès patvirtinimui reikalingi vaizdo tyrimo metodai, iš kuriu pirmumas teikiamas kompiuterinei tomografijai su intraveniniu kontrastavimu. ŪMI gydymas pradeda- mas paciento būklės stabilizavimu: kristaloidų infuzija, nazogastrinio zondo iqvedimas, plataus spektro antibi- otikai, heparinas. Specifinis gydymas apima atvirus ir endovaskulinius metodus, kurių tikslas - kuo greičiau atkurti normalią žarnyno kraujotaką.}

\section{Ivadas}

Ūmi mezenterinè išemija (ŪMI) - tai staigiai sumažèjusi ar visiškai nutrūkusi kraujo tėkmė i plonają žarną ar jos segmentą, sukelianti išemiją, ląstelių pažeidimą, nekrozę, nevaldomą uždegiminį atsaką ir mirtị. Ši būkle sudaro 0,1 proc. skubiosios hospitalizacijos [1,2]. Galima išemijos etiologija yra arterijos embolija (40-50\%) arba trombozè (25\%), kiti atvejai susiję su venų tromboze ir neokliuzinèmis priežastimis (hipovolemija, sepsis, širdies nepakankamumas) [1,3].
Viršutinè mezenterinè arterija yra dažniausia trombembolijos vieta [4]. Ūmi mezenterinè išemija dažniausiai pasireiškia stipriu pilvo skausmu, kuris neatitinka apžiūros radinių, t.y. kol neišsivysto transmuralinis žarnos infarktas, palpacija gali būti beveik neskausminga, be pilvaplèvès dirginimo reiškinių ir tai apsunkina diagnozę. Ankstyva diagnozė ir skubus gydymas yra būtini, siekiant sumažinti mirštamumą nuo šios ligos, kuris šiuo metu yra 40-80 procentų. Kiekvienos uždelstos 24 val. padidina mirštamumą 20 procentų [2,3,5].

Tyrimo tikslas - aptarti ūmios mezenterinès išemijos etiologiją, diagnostiką ir gydymą. Straipsnyje ŪMI tapatinama su mezenterinių arterijų okliuzija. ŪMI dèl mezenterinių venų embolijos ir neokliuzinių priežasčių neaptariama.

\section{Tyrimo medžiaga ir metodai}

Literatūros paieška atlikta PubMed, ScienceDirect, UpToDate duomenų bazèse. Naudoti raktažodžiai: acute mesenteric ischemia, guidelines, treatment, acute mesenteric arterial occlusion. Iš viso atrinkta ir išanalizuota 10 publikacijų, paskelbtų 2013-2020 metų laikotarpiu.

\section{Tyrimo rezultatai}

Etiologija. Ūmi viršutinès mezenterinès arterijos okliuzija gali atsirasti dèl dviejų priežasčių: embolija arba trombozė [6]. Embolija sudaro 22-50 proc. visų ŪMI atvejų. Embolai gali būti iš kairiojo prieširdžio esant prieširdžių virpejjimui, kairiojo skilvelio (po persirgto miokardo infarkto), nuo širdies vožtuvų dèl endokardito, dèl aortos aterosklerozès. Viršutinè mezenterinè arterija pažeidžiama, nes atsišakoja nuo aortos mažesniu kampu negu truncus coeliacus ar apatinė mezenterinė arterija. Embolas dažniausiai ìstringa $3-10 \mathrm{~cm}$ už atsišakojimo nuo aortos, už vidurinès storosios žarnos arterijos atsišakojimo, o iki 15 proc. embolu ìstringa atsišakojime nuo aortos. Vidurinis tuščiosios žarnos segmentas dažniausiai įtraukiamas ị išeminị procesą, o proksimalinė tuščiosios žarnos dalis dažnai lieka sveika $[1,3,5]$. Arterijos trombozé sudaro $25-30$ proc. visų ŪMI atvejų. Pagrindiniai rizikos veiksniai yra aterosklerozè ir dislipide- 
mija, hipertenzija, diabetas, antifosfolipidinis sindromas ir estrogenų terapija. Daugelio pacientų anamnezejje yra lètinès mezenterinès išemijos simptomų: pilvo skausmas pavalgius, svorio kritimas ar maisto baimè. Trombozè paprastai įvyksta kraujagyslių atsišakojimuose, šiuo atveju viršutinès mezenterinès arterijos atsišakojime nuo aortos. Mezenterinių arterijų trombozè gali ịvykti dèl trauminio kraujagyslès pažeidimo, infekcijos, disekacijos, grybelinès kilmès aneurizmos. Jei anksčiau buvo stentuotos mezenterinès kraujagyslès, gali būti stento trombozè $[1,3,5]$.

Diagnostika. Ankstyvieji ŪMI simptomai ir požymiai, iskaitant laboratorinius tyrimus ir apžvalgines rentgeno nuotraukas, nespecifiški, todèl svarbu ịtarti galimą ŪMI, ypač pacientams, turintiems rizikos veiksnių (prieširdžių virpèjimas, neseniai persirgtas miokardo infarktas, periferiniu kraujagyslių liga, lètinès mezenterinės išemijos simptomai). ŪMI negalima atmesti, jeigu pacientui staigiai prasidejo nuolatinis, pagal klinikinius radinius neproporcingai stiprus pilvo skausmas, kol nèra tikslios diagnozès [1,2]. Jei apžiūrint pacientą yra peritonito klinika, esant ŪMI dažnai tai reiškia negrị̌tamus išeminius pakitimus su žarnų nekroze. Kiti simptomai esant ŪMI: pykinimas (44\%), vėmimas (35\%), viduriavimas (35\%), kraujas tiriant per rectum (16\%). Pavèluotai diagnozuojant, galimas septinis šokas [3]. Dažniausiai randami laboratorinių tyrimų nukrypimai: hemokoncentracija, leukocitozè, metabolinè acidozè, didelè laktato, amilazès, asparagininès aminotransferazès koncentracija. Nei vienas iš šių rodiklių nèra pakankamai jautrus ar specifiškas, diagnozuojant ŪMI. Tiriami keli biožymenys, kurie ateityje potencialiai galètų būti naudojami ankstyvam ŪMI diagnozavimui. Šie žymenys yra: žarnų riebalų rūgštis sujungiantis baltymas (I-FABP), $\alpha$ - gliutationo $\mathrm{S}$ - transferazè (GST) [2]. ŪMI diagnostikoje būtini vaizdo tyrimai. Apžvalginèje pilvo rentgenogramoje galima matyti išsiplètusias žarnų kilpas, kartais žarnos sienelès edemą, tačiau šie pakitimai atsiranda vèlai. Normali rentgenograma nepadeda atmesti ŪMI. Ultragarsu galima apžiūrèti truncus coeliacus ir viršutinę mezenterinę arteriją. Doplerio režimas yra specifiškas (92-100\%), bet nelabai jautrus (70-89\%) identifikuojant kraujagyslių okliuziją. Šis tyrimas leidžia atmesti nemažai kitų pilvo skausmo priežasčių, tačiau diagnozuoti ŪMI nerekomenduojamas dèl nesèkmingo tyrimo galimybès. Magnetinio rezonanso tomografija su kontrastavimu gadoliniu yra jautrus ir specifiškas metodas, nustatant viršutinės mezenterinès arterijos stenozę ar obstrukciją. Šis tyrimas neefektyviai vizualizuoja distalines šakas, užtrunka pakankamai ilgą laiką ir neparodo aterosklerotinių plokštelių (kalcio) kraujagyslių sienelèse. Kompiuterinè tomografija (KT) su intraveniniu kontrastavimu yra pirmo pasirinkimo tyrimas įtariant ŪMI, bei leidžia atmesti daugelị kitų ūmaus pilvo skausmo priežasčių. Šs tyrimas greitai atliekamas, pacientai ji gerai toleruoja ir galima ištirti dideli plotą. Rekomenduojama atlikti skenavimą ir arterinejje, ir veninejje fazejje. Tai leidžia identifikuoti trombus arterijose ir venose, įvertinti kontrasto kaupimą žarnų sienelèje. Vaizduose be kontrasto galima ịvertinti kalcifikatus kraujagyslių sienelëje [5].

Gydymas. Ūmios mezenterinès išemijos gydymas pradedamas kristaloidų infuzija ị veną. Taip palaikomas intravaskulinis tūris ir organų perfuzija. Reikètų ịvertinti ir koreguoti elektrolitų kiekị ir šarmų - rūgščių balansą, nes esant ŪMI vystosi metabolinė acidozė ir hiperkalemija. Turi būti įvedamas nazogastrinis zondas $[1,3]$. Rekomenduojama vengti vazopresorių, tačiau esant vazopresorių poreikiui koregavus hipovolemiją, rinktis vaistus, kurie turi minimalų poveiki žarnyno kraujotakai (dobutaminas, dopaminas mažomis dozėmis ar milrinonas) [2]. Dẻl išemijos žarnų sienelès gleivinè praranda vientisumą, ìvyksta bakterijų translokacija ir labai padideja infekcijų rizika. Nustačius ŪMI, rekomenduojama skirti plataus spektro antibiotikus, pvz.: penicilinas arba trečios kartos cefalosporinas su metronidazoliu [2,3]. Siekiant sustabdyti tolesnị trombų didèjimą ir nesant absoliučių kontraindikacijų, ị veną suleidžiama nefrakcionuoto heparino $[1,3]$. Pagrindinis gydymo tikslas yra kuo greičiau atkurti normalią žarnyno kraujotaką. Specifinio gydymo pasirinkimas priklauso nuo to, ar išemijos kilmé yra embolizacija, ar trombozè (tai dažniausiai galima pasakyti atlikus KT tyrimą). Jei yra embolija, plačiausiai taikomas gydymas yra atvira embolektomija, tačiau esant techninių galimybių, reikètų bandyti endovaskulinius gydymo metodus (mechanine embolo aspiracija, lokali trombolize su angioplastika ir stentavimu, kai reikia) [1,2]. Esant trombozei, pirmo pasirinkimo gydymo metodas turètų būti endovaskulinis (angioplastika ir stentavimas). Endovaskuliniai gydymo metodai gali būti taikomi esant grižtamiesiems žarnų pakitimams [2]. Lyginant atviros operacijos ir endovaskulinio gydymo baigtis, bendras mirštamumas buvo 27 proc., bet endovaskulini gydymą gavusių pacientų mirštamumas buvo mažesnis, nei operuotų atviruoju būdu (santykinè rizika 0,68 ), taip pat endovaskulinis gydymas susijęs su mažesne žarnų rezekcijos ir second-look laparotomijos rizika [7]. Jeigu yra ryškių peritonito požymių (tai parodo jau ịvykusią katastrofą pilve), indikuotina skubi laparotomija. Šios operacijos tikslas yra žarnų kraujotakos atkūrimas, negrịžtamai pakitusios žarnos pašalinimas ir dar gyvybingos žarnos išsaugojimas [3]. Likus mažiau nei $100 \mathrm{~cm}$ plonosios žarnos, dažniausiai vystosi žarnų nepakankamumas ir gali būti reikalinga pilna parenterinè mityba. Visiškos parenterinès mitybos terapijos prireikia 13-31 proc. pacientų, išgyvenusių po ÜMI [2]. Pacientams su sepsiu ar septiniu šoku turètų būti atlikta gyvybę gelbstinti žalos kontrolès (damage control) operacija: laparotomija ir 
negyvybingos žarnos rezekcija (be anastomozès ar stomos) ir trombektomija (jeigu indikuotina). Po 48 val. reikia atlikti second-look laparotomiją ir ịvertinti žarnų gyvybingumą po kraujotakos atkūrimo, tai taip pat tinkamas laikas anastomozès suformavimui [2].

\section{Išvados}

1. Ümi viršutinès mezenterinès arterijos okliuzija atsiranda dèl embolijos arba trombozès.

2. Ankstyvieji ŪMI simptomai ir požymiai, įskaitant laboratorinius tyrimus ir apžvalgines rentgeno nuotraukas, yra nespecifiški, todèl svarbu įtarti šią ligą. KT yra pirmo pasirinkimo metodas diagnozès patvirtinimui.

3. ŪMI gydymas pradedamas adekvačia skysčiu terapija, nazogastrinio zondo ịvedimu, plataus spektro antibiotikais, heparinu. Pagrindinis tikslas - atkurti žarnyno kraujotaką atviros operacijos ar endovaskuliniais metodais.

\section{Literatūra}

1. Pearl G, Gilani R. Acute mesenteric arterial occlusion.UpToDate 2021. https:/www.uptodate.com/contents/acute-mesentericarterial-occlusion?search $=$ acute $\% 20$ mesenteric $\% 20$ ischemia \& topicRef $=2559$ \& source $=$ see_link

2. Tilsed JVT, Casamassima A, Kurihara H, Mariani D, Martinez I, Pereira J, et al. ESTES guidelines: acute mesenteric ischaemia. Eur J Trauma Emerg Surg 2016;42:253-70. https://doi.org/10.1007/s00068-016-0634-0

3. Bala M, Kashuk J, Moore EE, Kluger Y, Biffl W, Gomes CA, et al. Acute mesenteric ischemia: guidelines of the World Society of Emergency Surgery. World J Emerg Surg 2017;12(1):38. https://doi.org/10.1186/s13017-017-0150-5

4. McGarry JG, McEvoy SH, Brophy DP. Endovascular recanalisation of an acute superior mesenteric artery occlusion. A case report and review of the literature. Ann Med Surg 2015;4(1):76-9. https://www.sciencedirect.com/science/article/ pii/S2049080114000594

https://doi.org/10.1016/j.amsu.2014.07.005
5. Navas-Campo R, Moreno-Caballero L, Ezponda Casajús A, Ibáñez Muñoz D. Acute mesenteric ischemia: a review of the main imaging techniques and signs. Radiol Engl Ed 2020;62(5):336-48. https://www.sciencedirect.com/science/ article/pii/S2173510720300501

https://doi.org/10.1016/j.rxeng.2020.02.004

6. Franca E, Shaydakov ME, Kosove J. Mesenteric artery thrombosis. StatPearls Publishing 2021. http://www.ncbi.nlm.nih. gov/books/NBK539763/

7. Rebelo A, Partsakhashvili J, John E, Kleeff J, Ukkat J. Current concepts and evidence on open, endovascular and hybrid treatment of mesenteric ischemia: the retrograde open mesenteric stenting. Surg Pract Sci 2020;100022. https:/www.sciencedirect.com/science/article/pii/S2666262020300206

https://doi.org/10.1016/j.sipas.2020.100022

\section{ACUTE MESENTERIC ARTERIAL OCCLUSION. ETIOLOGY, DIAGNOSIS, TREATMENT \\ J. Rimkus}

Keywords: acute mesenteric ischemia, guidelines, treatment, acute mesenteric arterial occlusion.

\section{Summary}

Acute mesenteric ischemia is a condition characterized by an interruption of blood flow to varying fragments of small intestine. Mortality rate from this disease is $40-80 \%$. The most common etiology is embolization or thrombosis of the superior mesenteric artery. Early diagnosis is difficult due to nonspecific signs, symptoms and laboratory results. Computed tomography scan is the first choice imaging technique to confirm suspected acute mesenteric ischemia. When diagnosis is made, treatment should begin with adequate fluid resuscitation, electrolyte abnormalities should be corrected, broad spectrum antibiotics should be administered and the patient should be anticoagulated with unfractionated heparin. Specific treatment includes open and endovascular methods to restore intestinal blood flow as soon as possible.

Correspondence to: juozas.rimkus96@gmail.com

Gauta 2021-04-29 